Forestry and Grassland; Received on: 05/05/2020 Accepted on: 09/06/2020

\title{
Morphological and yield responses of spineless cactus Orelha de Elefante Mexicana under different cutting intensities
}

Respostas morfológicas e produtivas da palma-forrageira Orelha de Elefante Mexicana em diferentes intensidades de corte

PEREIRA, Juliana de Souza ${ }^{1}$

https://orcid.org/0000-0003-3107-8487

CAVALCANTE, Anderson Barbosa ${ }^{1}$

https://orcid.org/0000-0001-5079-4759

NOGUEIRA, George Henrique Melo de Sá

Marquim Ferraz ${ }^{1}$

https://orcid.org/0000-0002-1606-7344
CAMPOS, Fleming Sena ${ }^{2}$

https://orcid.org/0000-0001-9027-3210

ARAÚJO, Gherman Garcia Leal de ${ }^{3}$ https://orcid.org/0000-0001-9605-1096

SIMÕES, Welson Lima3;

https://orcid.org/0000-0003-1474-9410

VOLTOLINI, Tadeu Vinhas ${ }^{3 *}$

https://orcid.org/0000-0001-8793-8103

\footnotetext{
${ }^{1}$ Universidade Federal do Vale do São Francisco (Univasf), Petrolina, Pernambuco, Brazil;

${ }^{2}$ Universidade Federal do Agreste Pernambucano (UFAPE), Garanhuns, Pernambuco, Brazil.

${ }^{3}$ Embrapa Semiárido, Petrolina, Pernambuco, Brazil.

*Corresponding author: tadeu.voltolini@embrapa.br
}

\begin{abstract}
The objective was to evaluate the effects of different cutting intensities on the morphological responses and forage yield of spineless cactus Orelha de Elefante Mexicana (OEM) (Opuntia stricta (Haw.) Haw) in a 12-month cycle, receiving supplemental irrigation. Three cutting intensities were evaluated: cut preserving only the mother cladode (MOTHC), cut preserving primary cladodes (PRIMC), and cut preserving secondary cladodes (SECC), equivalent to initial residual cladode area index (rCAI) of $0.08,0.33$ and 0.69 , respectively. The experiment was a randomized block design with eight replicates. The cutting intensities PRIMC and SECC resulted in higher plant height and width, total cladode number and cladode area index compared to MOTHC. The harvested plant weight, forage yield $\left(\mathrm{t} \mathrm{DM} \mathrm{ha}{ }^{-1}\right)$, forage accumulation rate and water use efficiency were greater for PRIMC and SECC in comparison to MOTHC. The forage yield for MOTHC was 20.92 t DM (dry matter) ha ${ }^{-1}$, while for PRIMC and SECC were 37.55 and $33.18 \mathrm{t} \mathrm{DM} \mathrm{ha}^{-1}$, respectively. The final CAI was 1.23, 2.53 and 3.55 for MOTHC, SECC and PRIMC, respectively. Morphological and yield responses of OEM Spineless cactus under supplemental irrigation are influenced by cutting intensities, in which less intense cuts (preserving the primary or secondary cladodes) promote taller and wider plants, and higher forage yield.
\end{abstract}


Key words: cutting height, forage, Opuntia stricta (Haw.) Haw, semi-arid, supplemental irrigation

\section{RESUMO}

Objetivou-se avaliar os efeitos de diferentes intensidades de corte sobre as respostas morfológicas e produtivas da palma-forrageira Orelha de Elefante Mexicana (OEM) (Opuntia stricta (Haw.) Haw) em um ciclo de 12 meses, recebendo irrigação suplementar. Foram avaliadas três intensidades de corte: corte preservando apenas o cladódio-mãe (CMOTH), corte preservando os cladódios primários (CPRIM) e corte preservando os cladódios secundários (CSEC), equivalentes ao índice de área de cladódios residuais (IACr) de 0,08; 0,33 e 0,69, respectivamente. O delineamento experimental foi em blocos casualizados, com oito repetições. As intensidades de corte CPRIM e CSEC proporcionaram maior altura e largura de planta, número total de cladódios e índice de área de cladódio em comparação com o CMOTH. O peso colhido na planta, a produtividade ( $\mathrm{t}$ de matéria seca $\mathrm{ha}^{-1}$ ), a taxa de acúmulo de forragem e a eficiência no uso da água foram maiores para o PRIMC e CSEC quando comparada ao CMOTH. A produção de forragem para CMOTH foi $20,92 \mathrm{t} \mathrm{MS} \mathrm{(material} \mathrm{seca)} \mathrm{ha}^{-1}$, enquanto para CPRIM e CSEC foram 37,55 e 33,18 $\mathrm{t} \mathrm{MS} \mathrm{ha}^{-1}$, respectivamente. Os IAC finais foram 1,23, 2,53 e 3,55 para CMOTH, CSEC e CPRIM, respectivamente. As respostas morfológicas e a produção da palma-forrageira Orelha de Elefante Mexicana recebendo irrigação suplementar são influenciadas pela intensidade de corte, em que cortes menos intensos (preservando os cladódios primários ou secundários) promovem plantas mais altas e largas e maior produção de forragem.

Palavras-chave: altura de corte, forragem, Opuntia stricta (Haw.) Haw, semiárido, irrigação suplementar

\section{INTRODUCTION}

Spineless cactus (Opuntia sp. and Nopalea sp.) is one of the most important forage resources in the Brazilian semiarid region presenting large water reserve, tolerant to drought, easily propagated, without the necessity of storage even during dry periods (Marques et al., 2017). The spineless cactus may supply a large part of the water for the herd during periods of scarcity (Nogueira et al., 2011; Almeida et al., 2015).

In the Brazilian semi-arid region, in recent years, the Spineless cactus Orelha de Elefante Mexicana (OEM) has been disseminated for use in livestock systems
(Silva et al., 2017; Monteiro et al., 2019). According to Rocha et al. (2017), the use of additional water application for irrigation of Spineless cactus has also increased, especially in drier regions. The water supply by irrigation may promote changes in plant growth when compared to rainfed forage cactus, demanding the generation of new management strategies for irrigated spineless cactus, as the cut management. Lima et al. (2016) and Rego et al. (2014) reported higher forage yield for Spineless cactus "Gigante" (Opuntia ficus indica) and "Miuda" (Nopalea Cochenillifera Salm-Dyck), respectively, by cutting the plant and preserving the secondary cladodes 
compared to the cut preserving the mother or primary cladodes. However, the Orelha de Elefante Mexicana has a different growth (more lateral) than Gigante and Miuda.

Sunlight has great importance for spineless cactus since the cladode arrangement is almost perpendicular to the ground, with a low cladode area index hindering the interception of the incident light, which results in slow initial growth due to the small photosynthetic area (Nobel, 2001), affecting growth dynamics and forage yield (Cavalcante et al., 2014; Silva et al., 2014). A greater number of preserved cladodes will imply a larger photosynthetic area that may provide faster regrowth and greater productivity. It has been hypothesized that less intense cutting in spineless cactus Orelha de Elefante Mexicana increases forage production.

Despite scientific advances regarding the effects of crop management on morphological responses and forage yield in spineless cactus, there is still a gap in the literature as to research on the management of this forage resource under supplemental irrigation. Therefore, the present study aimed at evaluating the effects of different cutting intensities on morphological responses and forage yield in spineless cactus Opuntia stricta (Haw.) Haw, in a cycle of 12 months, receiving supplemental irrigation.

\section{MATERIAL AND METHODS}

The present study was carried out at Embrapa Semiárido, the Brazilian Agricultural Research Corporation, Petrolina, State Pernambuco, Brazil. The spineless cactus genotype used was Orelha de Elefante Mexicana (OEM)
(Opuntia stricta (Haw.) Haw), with three year after planting at the beginning of the experiment. In the trial period, rainfall was $341 \mathrm{~mm}, \quad$ reference evapotranspiration (ETo) 1,840 $\mathrm{mm}$, mean temperature $26.4{ }^{\circ} \mathrm{C}$, and mean relative humidity $59.3 \%$.

The treatments were characterized by cutting intensities, which were: 1 preserving only mother cladodes (MOTHC), 2 - preserving all primary cladodes (PRIMC), 3 - preserving all secondary cladodes (SECC), converted into initial residual cladode area index (rCAI), with values of $0.08,0.33$ and 0.69 , respectively. The cutting interval was 12 months and the planting density was 43,478 plants per hectare.

The experiment was a randomized block design with three treatments and eight replicates, each plot consisting of 25 plants in the useful area, with analysis of five plants inside the useful area of each plot, totaling 120 evaluated plants.

Crop irrigation was carried out according to reference evapotranspiration and was supplemental to rainfall, through drip irrigation, using a drip tape with flat drippers and was set at every 15 days with a supply of $779.48 \mathrm{~mm}$ via irrigation. The chemical composition of irrigation water was: $\mathrm{Ca}^{2+}=0.43 \mathrm{mmol}$ $\mathrm{L}^{-1}, \mathrm{Mg}^{2+}=0.52 \mathrm{mmol} \mathrm{L}-1, \mathrm{Na}^{+}=0.14$ $\mathrm{mmol} \mathrm{L}-1, \mathrm{~K}^{+}=0.05 \mathrm{mmol} \mathrm{L}^{-1}, \mathrm{CO}^{2-}=$ $0.00 \mathrm{mmol} \mathrm{L}^{-1}, \mathrm{HCO}^{3}-=0.62 \mathrm{mmol} \mathrm{L}^{-1}$, $\mathrm{SO}^{2-}=0.34 \mathrm{mmol} \mathrm{L}^{-1}, \mathrm{Cl}^{-}=1.60 \mathrm{mmol}$ $\mathrm{L}^{-1}, \mathrm{pH}=8.05$, electrictal conductivity $(E C)=0.06 \mathrm{ds} \mathrm{m}^{-1}$ and hardness $=4.76$ $\mathrm{mg} \mathrm{L} \mathrm{L}^{-1}$, classified as $\mathrm{C} 1 \mathrm{~S} 1$, or else, with low salinity hazard (Richards, 1954).

A standardization cut was made at the beginning of the trial, according to each treatment. At this point, the width and length of the residual cladodes were measured, estimating the cladode area for later estimation of rCAI. Also, a 
count of residual cladodes for each order was carried out, that is the number of primary cladodes (NPC), secondary cladodes (NSC), tertiary cladodes (NTC), quaternary cladodes (NQT), as well as the overall number of cladodes (NOC), corresponding to the average number of cladodes per plant.

Organic fertilization (tanned cattle manure) was applied at a rate equivalent to $40 \mathrm{t} / \mathrm{ha}$, and manual weeding was performed twice in order to control invasive plants. The chemical composition of the soil was: electric conductivity $(\mathrm{EC})=0.55 \mathrm{mS} \mathrm{cm}^{-1} ; \mathrm{pH}=$ $5.5 ; \mathrm{P}=6.35 \mathrm{mg} \mathrm{dm}^{-3} ; \mathrm{K}=0.35$ cmolc $\mathrm{dm}^{-3} ; \mathrm{Na}=0.08 \mathrm{cmolc} \mathrm{dm}^{-3} ; \mathrm{Ca}=1.7$

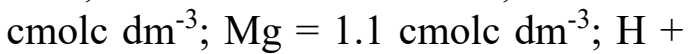
$\mathrm{Al}=2.6 \mathrm{cmolc} \mathrm{dm}^{-3}$; sum of bases (SB) $=3.2 \mathrm{cmolc} \mathrm{dm} \mathrm{dm}^{-3}$; cation exchange capacity $(\mathrm{CEC})=5.8 \mathrm{cmolc} \mathrm{dm}^{-3}$.

At harvest 12 months after the standardization cut, forage yield (forage mass (FM) in kg green matter (GM)) was evaluated by cutting and weighing three plants per plot (total of 24 plants per treatment). All cladodes of all orders were weighed for MOTHC, while for PRIMC, all cladodes from the second order onwards were weighed, and for SECC, only cladodes from the third order onwards, thus obtaining the weight of forage harvested per plant $(\mathrm{kg})$ for each cutting intensity.

Evaluations were also made for green productivity (GP) and dry productivity (DP) (t GM and t DM per ha), where the yield per hectare was estimated based on plant yield (weight of harvested forage) and the number of plants per hectare (plant yield $\mathrm{x}$ number of plants $\mathrm{ha}^{-1}$ ), as well as the morphological characteristics (plant height and width, number and size of cladodes) for both, the plant before cutting and the final residue, that is after 12 months of regrowth.
Dry matter (DM) content used for calculation of DP was obtained through the analysis of composite samples from cladodes of all orders of each plant, where the samples were taken to a forced ventilation oven at $55^{\circ} \mathrm{C}$ for pre-drying until constant weight.

At harvest, morphological measurements were taken for all cladodes of three plants from the useful area. A tape measure was used for measuring the plant height $(\mathrm{cm})$, considering the distance from the apex to the soil. The plant width $(\mathrm{cm})$ was measured considering the lateral extremities. After this, the number of cladodes per order was counted. Cladodes were also individually measured with a tape measure, defining length $(\mathrm{cm})$ and width $(\mathrm{cm})$ in order to determine the area and the cladode area index (CAI).

Cladode thickness $(\mathrm{cm})$ was measured according to the cladode order. Moreover, the width $(\mathrm{cm})$ and length (cm) of cladodes on the new residue were measured to estimate the area and the final rCAI for each treatment, as well as the number of cladodes on the final residue was counted per order.

Water use efficiency (WUE) was determined considering the rainfall volume plus the irrigation volume during 12 months and the forage yield (kg DM $\mathrm{ha}^{-1} /$ total volume of water (irrigation + rainfall)). Forage accumulation rate (FAR) was calculated considering the forage yield ( $\left.\mathrm{kg} \mathrm{DM} \mathrm{ha} \mathrm{ha}^{-1}\right)$ and the number of days ( $\mathrm{kg} \mathrm{DM} \mathrm{ha-1} / 365$ days). Data were tested by analysis of variance and Tukey's test; probability values under $5 \%(\mathrm{P}<0.05)$ were considered as significant. Statistical analyses were run in the Statistical Analysis System Software University Edition (SAS, 2015). 


\section{RESULTS AND DISCUSSION}

The cutting intensities PRIMC and SECC increased plant height and width compared to MOTHC. The cuts with higher initial rCAI (PRIMC and SECC) resulted in greater plant height than MOTHC; however, plant width for SECC was greater than for PRIMC (Table 1).
Less intense cuts resulted in taller and wider OEM plants (Table 1), due to the larger remaining photosynthetic area. The larger thickness of primary cladodes for PRIMC and SECC, compared to MOTHC, is because at the time of assessment, the primary cladodes were already at a more advanced maturity stage, as they had not been cut, being part of the residue remaining on the field in both of the treatments.

Table 1. Structural characteristics of Orelha de Elefante Mexicana (Opuntia stricta (Haw.) Haw) under different cutting intensities (preserving mother cladode MOTHC; preserving primary cladodes - PRIMC; preserving secondary cladodes - SECC) at 12 months of regrowth

\begin{tabular}{lllllll}
\hline \multirow{2}{*}{ Variable } & \multicolumn{3}{c}{ Cutting intensity } & SEM & \\
\cline { 2 - 4 } & $\begin{array}{l}\text { MOTHC } \\
\text { (rCAI=0.08) }\end{array}$ & $\begin{array}{l}\text { PRIMC } \\
(\mathbf{r C A I}=\mathbf{0 . 3 3})\end{array}$ & $\begin{array}{l}\text { SECC } \\
(\mathbf{r C A I}=\mathbf{0 . 6 9})\end{array}$ & & p-value \\
\hline Plant height $(\mathrm{cm})$ & $61.37 \mathrm{~b}$ & $88.37^{\mathrm{a}}$ & $94.5 \mathrm{a}$ & 1.69 & $<0.0001$ \\
Plant width $(\mathrm{cm})$ & $53.69 \mathrm{~b}$ & $91.5^{\mathrm{a}}$ & $111.43 \mathrm{a}$ & 3.12 & $<0.0001$ \\
NCr initial & $1 \mathrm{c}$ & $3.15 \mathrm{~b}$ & $7.02 \mathrm{a}$ & 0.28 & $<0.0001$ \\
NCr final & $1 \mathrm{c}$ & $4.3 \mathrm{~b}$ & $12.5 \mathrm{a}$ & 0.51 & $<0.0001$ \\
Overall number of cladodes & $11.34 \mathrm{~b}$ & $17.47 \mathrm{~b}$ & $24.75 \mathrm{a}$ & 0.93 & $<0.0001$ \\
Number of primary cladodes & 3.95 & 3.3 & 3.35 & 0.13 & 0.0645 \\
Number of secondary cladodes & 6.74 & 8.35 & 8.15 & 0.33 & 0.2009 \\
Number of tertiary cladodes & $0.89 \mathrm{c}$ & $5.72 \mathrm{~b}$ & $10.35 \mathrm{a}$ & 0.53 & $<0.0001$ \\
Number of quaternary cladodes & $0 \mathrm{c}$ & $0.08 \mathrm{~b}$ & $3.2 \mathrm{a}$ & 0.44 & $<0.0001$ \\
TPC (cm) & $1.40 \mathrm{~b}$ & $1.88^{\mathrm{a}}$ & $1.79 \mathrm{a}$ & 0.05 & 0.0001 \\
initial rCAI & $0.08 \mathrm{c}$ & $0.33 \mathrm{~b}$ & $0.69 \mathrm{a}$ & 0.03 & $<0.0001$ \\
final rCAI & $0.07 \mathrm{c}$ & $0.47 \mathrm{~b}$ & $1.58 \mathrm{a}$ & 0.07 & $<0.0001$ \\
Cladode area index overall & $1.23 \mathrm{c}$ & $2.53 \mathrm{~b}$ & $3.55 \mathrm{a}$ & 0.14 & $<0.0001$ \\
Cladode area index primary & 0.46 & 0.37 & 0.39 & 0.02 & 0.1835 \\
Cladode area index secondary & $0.76 \mathrm{~b}$ & $1.54^{\mathrm{a}}$ & $1.37 \mathrm{a}$ & 0.06 & $<0.0001$ \\
Cladode area index tertiary & $0.03 \mathrm{c}$ & $0.76 \mathrm{~b}$ & $1.69 \mathrm{a}$ & 0.09 & $<0.0001$ \\
Cladode area index quaternary & $0 \mathrm{c}$ & $0.01 \mathrm{~b}$ & $0.4 \mathrm{a}$ & 0.06 & $<0.0001$ \\
\hline
\end{tabular}

$\mathrm{NCr}=$ number of cladodes on the residue; TPC $=$ thickness of primary cladodes; $\mathrm{rCAI}=$ cladode area index for the initial residue; Mean values followed by different lowercase letters in the same row are significantly different by Tukey's test $(\mathrm{P}<0.05)$. SEM $=$ Standard Error of the Mean.

The cutting intensity did not influence the thickness of overall cladodes nor the thickness of secondary cladodes, tertiary cladodes or quaternary cladodes. Nevertheless, there was an increase in primary cladode thickness (Table 1) for 
spineless cactus PRIMC and SECC when compared to MOTHC, with no difference between PRIMC and SECC.

There was a significant difference in the overall number of cladodes, as well as tertiary and quaternary cladodes, with a progressive increase the greater the number of preserved cladodes on the respective residues (Table 1), wherein SECC stood out among all mentioned variables.

The greater number of cladodes on the plant at 12 months after cutting for SECC in comparison to PRIMC and for both when compared to MOTHC (Table 1) is also due to the greater number of initial cladodes. PRIMC and especially SECC provided cladodes of the fourth order, representing a different phenological stage when compared to MOTHC. The appearance of fourth order cladodes for PRIMC and SECC occurred also due to the less intense cutting of these plants at the beginning of the trial, with primary and secondary cladodes remaining on the residue.

There was no significant difference in NPC and NSC. Nonetheless, there was a significant difference as to NTC and NQC, where SECC caused the appearance of a greater number of tertiary cladodes than PRIMC and both promoted greater NTC than MOTHC (Table 1).

The lack of differentiation for NPC and NSC indicates that at 12 months after cutting, regardless the cutting intensity, the number of cladodes of the first and second order has stabilized, with a reduction in the emergence rate for new primary and secondary cladodes, initiating a new phenological growth stage, where the emergence rate for the new order is greater than for cladodes of the previous orders.

Differences detected between NOC,
NTC and NQC (Table 1) indicate that preserving a larger photosynthetic area and a greater number of cladodes on the residue directly influences the regrowth capacity of the plant, insofar as the larger cladode area directly implies a larger number of areolas, structures which are equivalent to axillary buds and, under appropriate environmental conditions, can bring forth new cladodes (ReyesAgüero et al., 2006).

Moreover, the difference in values for NTC and NQC, where the increase in rCAI promoted the emergence of a greater number of cladodes, indicates that the plants in each of the treatments were at different phenological stages. According to Amorim et al. (2017), phenology deals with the different externally visible stages of plants, stages known as phenophase, being that the indicator for a change in the phenological stage, regarding spineless cactus, is the emergence rate of cladodes per order of emergence. Therefore, the plants in the group preserving all second order cladodes were already about to start a new phenological stage (emission of tertiary cladodes, also known as phenophase III) (Amorim et al., 2017).

Plants in MOTHC and PRIMC treatments would have to restart the other phenological stages (emergence of primary and secondary cladodes for MOTHC, and secondary cladodes for PRIMC), and only after that, start the stage where tertiary and quaternary cladodes appear (a stage which was not achieved within 12 months, as observed in Table 1), wherein according to Amorim et al. (2017), the length of phenophase I for Opuntia stricta (Haw.) Haw is 7 months, denoting that the cutting intensity caused morphological and structural changes in the spineless cactus Orelha de Elefante Mexicana. 
While at 12 months after cutting, plants in the treatment MOTHC started emitting third order cladodes, PRIMC plants were at the middle of the third order, and SECC plants were beginning to produce the fourth order (Table 1).

No difference in primary CAI was found between the cutting intensities. However, there was a significant difference in the overall CAI and in the CAI for first, second and third orders (Table 1).

The increase in CAI stands in direct relation to the photosynthetic capacity of the plant, since the cladodes of spineless cactus are responsible for harnessing solar radiation for carbohydrate biosynthesis, which was confirmed in the present study by the proportional increase in initial rCAI and number of produced cladodes (Table 1).

The rCAI at the beginning of the trial was 0.33 and 0.69 for PRIMC and SECC, respectively, while after 12 months after cutting, rCAI values were 0.47 and 1.58, having strengthened support structures for growth and completed the development of the primary and secondary orders.

The cutting intensity did not influence the weight of primary and quaternary cladodes. There was a significant difference as to the harvested weight per plant, weight of secondary and tertiary cladodes, green productivity (GP) and dry productivity (DP), forage accumulation rate (FAR), and water use efficiency (WUE).

The harvested weight per plant was higher for PRIMC compared to MOTHC, but both were similar to SECC. The weight of secondary cladodes was higher for PRIMC in comparison to MOTHC. Plants with SECC showed greater weight for third order cladodes when compared to the others. Productivity (kg GM ha- ${ }^{1}$ ) was greater for PRIMC in relation to MOTHC. Regarding $\mathrm{kg} \mathrm{DM} \mathrm{ha}^{-1}$, the productivity for plants with MOTHC was lower than for the others, as for FAR (Table 2).

The observed differences in productivity, on the other hand, are possibly associated with a greater remaining CAI after cutting that allowed for greater photosynthetic efficiency, which may have occurred between PRIMC and MOTHC for harvested weight per plant and green productivity. Nobel (2001) reports that the existence of a greater number of cladodes per unit area tends to increase the $\mathrm{CO}_{2}$ uptake and maximize productivity. Both, a greater remaining cladode area index after the cut and the existence of a greater number of cladodes per unit area, were observed in the present trial (Table 1), thus corroborating the above statements. 
Table 2. Productive responses of spineless cactus Orelha de Elefante Mexicana (Opuntia stricta (Haw.) Haw) under different cutting intensities (preserving mother cladode - MOTHC, preserving primary cladodes - PRIMC and preserving secondary cladodes - SECC) at 12 months of regrowth.

\begin{tabular}{|c|c|c|c|c|c|}
\hline \multirow[b]{2}{*}{ Variable } & \multicolumn{3}{|c|}{ Cutting intensity } & \multirow[b]{2}{*}{ SEM } & \multirow[b]{2}{*}{ p-value } \\
\hline & $\begin{array}{l}\text { MOTHC } \\
(\mathrm{rCAI}=0.08)\end{array}$ & $\begin{array}{l}\text { PRIMC } \\
(\mathrm{rCAI}=0.33)\end{array}$ & $\begin{array}{l}\text { SECC } \\
(\mathrm{rCAI}=0.69)\end{array}$ & & \\
\hline Harvested weight (kg plant $\left.{ }^{-1}\right)$ & $5.14 \mathrm{~b}$ & $8.30 \mathrm{a}$ & $6.30 \mathrm{ab}$ & 0.37 & 0.0026 \\
\hline Weight of primary cladode $(\mathrm{kg})$ & 2.35 & 0 & 0 & 0.10 & - \\
\hline Weight of secondary cladode (kg) & $2.52 \mathrm{~b}$ & $5.91 \mathrm{a}$ & 0 & 0.26 & $<0.0001$ \\
\hline Weight of tertiary cladode $(\mathrm{kg})$ & $0.75 b$ & $2.46 b$ & $5.42 \mathrm{a}$ & 0.30 & $<0.0001$ \\
\hline Weight of quaternary cladode $(\mathrm{kg})$ & 0 & 0.39 & 1.67 & 0.11 & 0.1465 \\
\hline Forage yield (t GM ha-1) & $223.4 b$ & $360.8 \mathrm{a}$ & $273.8 \mathrm{ab}$ & 16.1 & 0.0026 \\
\hline Forage yield (t DM ha-1) & $20.92 b$ & $37.55 \mathrm{a}$ & $33.18 \mathrm{a}$ & 1.89 & 0.0018 \\
\hline FAR (kg DM ha-1 day $\left.^{-1}\right)$ & $57.32 b$ & $102.89 \mathrm{a}$ & $90.90 \mathrm{a}$ & 5.17 & 0.0018 \\
\hline WUE (kg DM ha $\left.{ }^{-1} \mathrm{~mm}^{-1}\right)$ & $16.82 b$ & $33.51 \mathrm{a}$ & $29.61 \mathrm{a}$ & 1.68 & 0.0018 \\
\hline
\end{tabular}

$\mathrm{GM}=$ green matter; $\mathrm{DM}=$ dry matter; $\mathrm{FAR}$ = forage accumulation rate; $\mathrm{WUE}=$ water use efficiency; $\mathrm{rCAI}=$ residual cladode area index. Mean values followed by different lowercase letters in the same row are significantly different by Tukey's test $(\mathrm{P}<0.05)$. SEM $=$ Standard Error of the Mean.

This difference may also be related to root biomass, as the spineless cactus allocates about $81 \%$ dry biomass to the aerial part and the remaining $19 \%$, to the root (Teles et al., 2002), ergo if there is more biomass in the shoots, there is also more biomass in the roots. The roots are a means of water and nutrient uptake from the soil and the productive capacity of the shoots of a plant results from its root system as well (Edvan et al., 2013). However, in the present trial, no significant difference was detected between the cut preserving secondary cladodes and the cut preserving primary cladodes, regarding secondary CAI (Table 1), harvested weight per plant, GP and FAR (Table 2). The lack of difference for harvested weight per plant and for GP between PRIMC and SECC, and between SECC and MOTHC (Table 1) is probably related to the fact that, although there is a greater overall number of cladodes for SECC (Table 1), only cladodes of the third and fourth orders were harvested, which are in greater number for this kind of cut, even though they are still in development; while for PRIMC, in addition to tertiary and quaternary cladodes, also the secondary cladodes were harvested, which are older and already fully grown; and for MOTHC, all cladodes of the first, second and third orders were removed. Even though the less intense cutting promotes a greater number of cladodes per plant (Table 1), and this overall number of cladodes is correlated to the biomass yield, and though the less intense cutting leads to a greater capacity of biomass production indicated by the larger cladode area index (Table 1), the combination of harvested orders results in statistical similarity of productive variables between PRIMC and SECC, and between SECC and MOTHC (Table 2).

Given the above, it was observed that the 
preservation of a larger residual area promoted a greater accumulation of cladodes, leading to a higher CAI of the plant (Table 1). It is probably related to the greater photosynthetic capacity, providing superior FAR, which promotes higher weight per plant and productivity, being more efficient in water use (Table 2), considering that WUE for PRIMC and SECC were underestimated since with these cuttings not all cladodes were harvested.

Different cutting intensities influence morphological responses and forage yield in spineless cactus Orelha de Elefante Mexicana (Opuntia stricta (Haw.) Haw), under supplemental irrigation. Cuts preserving primary cladodes or secondary cladodes result in taller and wider plants and greater forage yield.

\section{ACKNOWLEDGMENTS}

This study was financed in part by the Coordenação de Aperfeiçoamento de Pessoal de Nivel Superior - Brasil (CAPES) - Finance Code 001. As well as with the support of Embrapa Semiárido through research aid $\left(n^{\circ}\right.$ 02.16.04.28.00.07).

\section{REFERENCES}

ALMEIDA, G.A.P.; CAMPOS, J.M.S.; FERREIRA, M.A.; CORREIA, A.L.V.; ANDRADE A.P. Palma (Opuntia ficus indica mill) cv. gigante em suplementos para fêmeas leiteiras em crescimento a pasto. Revista Caatinga. v.28, n.2, p.161-171, 2015.

AMORIM, D.M.; SILVA, T.G.F.; PEREIRA, P.D.C.; SOUZA, L.S.B.; MINUZZI, R.B. Phenophases and cutting time of forage cactus under irrigation and cropping systems.

Pesquisa Agropecuária Tropical. v.47, n.1, p.62-71, 2017.

LIMA, G.F.; REGO, M.M.T.; DANTAS, F.D.G.; LÔBO, R.N.B.; SILVA, J.G.M.; AGUIAR E.M. Morphological characteristics and forage productivity of irrigated cactus pear under different cutting intensities.

Revista Caatinga. v.29, n.2, p.481488, 2016.

CAVALCANTE, L.A.D.; SANTOS, G.R.A.; SILVA, L.M.; FAGUNDES, J.L.; SILVA, M.A. Respostas de genótipos de palma forrageira a diferentes densidades de cultivo.

Pesquisa Agropecuária Tropical. v.44, n.4, p.424-433, 2014.

EDVAN, R.L.; FERNANDES, P.D.; CARNEIRO, M.S.S.; NEDER, D.G.; ARAUJO, J.S.; ANDRADE, A.P.; SOUTO FILHO, L.T. Acúmulo de biomassa e crescimento radicular da palma forrageira em diferentes épocas de colheita. Revista Acadêmica:

Ciências Agrárias e Ambientais. v.11, n.4, p.35-43, 2013.

MARQUES, O.F.C; GOMES, L.S.P.; MOURTHÉ, M.H.F.; BRAZ, T.G.S.; PIRES NETO, O.S. Palma forrageira: cultivo e utilização na alimentação de bovinos. Caderno de Ciências Agrárias. v.9, n.1, p.75-93, 2017.

MONTEIRO, C.C.F.; FERREIRA, M.A.; VÉRAS, A.S.C.; GUIDO, S.I.; ALMEIDA, M.P.; SILVA, R.C.;

INÁCIO, J.G. A new cactus variety for dairy cows in areas infested with Dactylopius opuntiae. Animal Production Science. v.59, n.3, p.479485, 2019. 
NOBEL, P.S. Biologia Ambiental. In: BARBERA G, INGLESE P, PIMIENTA-BARRIOS E.

Agroecologia, cultivo e usos da palma forrageira. Roma: FAO/Sebrae-PB. p. 36-48. 2001.

NOGUEIRA, D.M.; VOLTOLINI, T.V.; MOREIRA, J.N.; LOPES JÚNIOR, E.S.; OLIVEIRA, V.G. Efeito de regimes alimentares sobre o peso corporal e parâmetros reprodutivos de cabras nativas. Archivos de Zootecnia. v.60, n.232, p.1339-1342, 2011.

REGO, M.M.T.; COSTA LIMA, G.F.; da SILVA, J.G.M.; DANTAS, F.D.G.; GUEDES, F.X.; LÔBO, R.N.B. Morfologia e rendimento de biomassa da palma miúda irrigada sob doses de adubação orgânica e intensidades de corte. Revista Científica de Produção Animal. v.16, n.2, p.118-130. 2015.

REYES-AGÜERO, J.A.; AGUIRRERIVESA, J.R.; VALIENTE-BANUET, A. Reproductive biology of Opuntia: A review. Journal of Arid

Environments. v.64, n.4, p.549-585, 2006.

RICHARDS, L.A. (ed). Diagnosis and improvement of saline and alkali soils. Agricultural Handook, n. 60. 160 p. 1954.

ROCHA, R.S.; VOLTOLINI, T.V.; GAVA, C.A.T. Características produtivas e estruturais de genótipos de palma forrageira irrigada em diferentes intervalos de corte. Archivos de Zootecnia. v.66, n.255, p.363-371, 2017.
SILVA, E.T.D.S.; MELO, A.A.S.D.; FERREIRA, M.D.A.; OLIVEIRA, J.C.V.D.; SANTOS, D.C.D.; SILVA, R.C.; INÁCIO, J.G. Acceptability by Girolando heifers and nutritional value of erect prickly pear stored for different periods. Pesquisa Agropecuária Brasileira. v.52, n.9, p.761-767, 2017.

SILVA, L.M.D.; FAGUNDES, J.L.; VIEGAS, P.A.A.; MUNIZ, E.N.; RANGEL, J.H.D.A.; MOREIRA, A.L.; BACKES, A.A. Produtividade da palma forrageira cultivada em diferentes densidades de plantio. Ciência Rural. v.44, n.11, p.2064-2071, 2014.

STATISTICAL ANALYSIS SYSTEM - SAS University Edition: SAS

Institute, 2015.

TELES, M.M.; SANTOS M.V.F.; DUBEUX JR, J.C.B.; BEZERRA NETO, E.; FERREIRA, R.L.C.; LUCENA, J.E.C.; LIRA, M.A. Efeito da adubação e de nematicida no crescimento e na produção da palma forrageira (Opuntia ficus indica Mill) cv Gigante. Revista Brasileira de

Zootecnia. v.31, n.1, p.52-60, 2002. 